\title{
Pengembangan Bahan Ajar Matematika Berbasis Ekonomi Syariah Untuk Madrasah Tsanawiyah
}

\author{
Mulin Nu'man \\ Program Studi Pendidikan Matematika Fakultas Sains dan Teknologi, UIN Sunan Kalijaga, Jl. Marsda \\ Adisucipto No. 1 Yogyakarta, Indonesia
}

Korespondensi; Email: mulin_numan@yahoo.com

\begin{abstract}
Abstrak
Penelitian ini bertujuan untuk mengembangkan bahan ajar matematika berbasis ekonomi syariah untuk madrasah tsanawiyah siswa dengan kualitas yang baik. Metode yang digunakan dalam penelitian ini adalah model pengembangan diadaptasi dari Borg \& Gall adalah awal tahap, pengembangan, dan validasi. Tahap awal meliputi studi literatur, analisis kebutuhan dan karakteristik siswa, dan untuk merencanakan dan memilih desain bahan ajar. Tahap pengembangan meliputi penentuan standar kompetensi, kompetensi dasar, indikator, dan materi pelajaran, menyusun bahan ajar matematika, dan mempersiapkan instrumen penelitian. Tahap validasi meliputi ahli validasi dan revisi. Hasil dari penelitian ini adalah aritmatika sosial bahan ajar berbasis ekonomi syariah. Setiap materi dimulai dengan masalah perbandingan ekonomi Islam dan konvensional. Kelayakan nilai bahan ajar adalah Sangat Baik untuk aspek tampilan dan sangat baik untuk aspek material. Dengan kriteria ini sangat baik, bahan pengajaran yang layak untuk digunakan dalam pembelajaran matematika dalam materi sosial aritmatika.
\end{abstract}

Kata Kunci: Bahan pengajaran; Ekonomi Islam; Madrasah Tsanawiyah

\begin{abstract}
This research aims to develop mathematical teaching materials based on sharia economy for madrasah tsanawiyah students with good quality. The method used in the study is the development model adapted from Borg \& Gall is the preliminary stage, development, and validation. The preliminary stage includes literature studies, analysis of the needs and characteristics of students, and to plan and choose the design of teaching materials. The development phase includes determining the competence standard, basic competence, indicators, and the subject matter, compiling teaching materials math, and prepare research instruments. The validation phase includes validation expert and revisions. Results of the study are social arithmetic teaching materials based on sharia economy. Each material begins with the problem of economic comparison of Islamic and conventional. The feasibility of the value of teaching materials is Very Good for aspects of the look and Very Good for the material aspects. With these criteria very well, teaching materials are feasible for use in the learning of mathematics in the social arithmetic material.
\end{abstract}

Keywords: Teaching materials; Islamic economics; Madrasah Tsanawiyah

\section{Pendahuluan}

Matematika adalah bahasa simbol yang berlaku secara internasional. Johnson dan Rising [8] menyatakan bahwa matematika adalah pola berpikir, ide, suatu seni, bahasa, dan pengetahuan. Perkembangan pesat di bidang teknologi informasi dan komunikasi dewasa ini dilandasi oleh perkembangan matematika di bidang teori bilangan, aljabar, analisis, teori peluang, dan matematika diskrit. Oleh karena itu, untuk menguasai dan mencipta teknologi di masa depan diperlukan penguasaan matematika yang kuat sejak dini.

Matematika merupakan salah satu mata pelajaran yang diajarkan pada setiap jenjang pendidikan di Indonesia mulai dari sekolah dasar (SD) sampai sekolah menengah atas (SMA) bahkan sampai perguruan tinggi (PT). Hal itu dilaksanakan karena matematika berperan sebagai raja bagi ilmu yang lain, dengan kata lain banyak ilmu-ilmu yang penemuan dan pengembangannya bergantung dari matematika 
misalnya ilmu fisika dan kimia. Mata pelajaran matematika perlu diberikan kepada semua siswa mulai dari sekolah dasar untuk membekali siswa dengan kemampuan berpikir logis, analitis, sistematis, kritis, dan kreatif, serta kemampuan bekerjasama. Kompetensi tersebut diperlukan agar siswa dapat memiliki kemampuan memperoleh, mengelola, dan memanfaatkan informasi untuk bertahan hidup pada keadaan yang selalu berubah, tidak pasti, dan kompetitif.

Penyelenggaraan pendidikan dasar dan menengah sebagaimana yang dinyatakan dalam Peraturan Pemerintah Nomor 17 Tahun 2010 tentang Pengelolaan dan Penyelenggaraan Pendidikan [9] bertujuan membangun landasan bagi berkembangnya potensi siswa agar menjadi manusia yang:

- beriman dan bertakwa kepad Tuhan Yang Maha Esa, berahlak mulia, dan berkepribadian luhur;

- berilmu, cakap, kritis, dan inovatif;

- sehat, mandiri percaya diri; dan

- toleran, peka sosial, demokratsis, dan bertanggungjawab.

Semua tujuan pendidikan di atas dapat terwujud apabila guru mampu merealisasikan pembelajaran yang mengarah pada tujuan tersebut.

Matematika merupakan ilmu pengetahuan yang penting bagi dunia pendidikan dan kehidupan. Salah satu karakteristik matematika adalah diterapkan atau diaplikasikan dalam ilmu lain atau dalam kehidupan sehari-hari. Perkembangan ilmu pengetahuan dan teknologi tidak lepas dari ilmu matematika.

Krisis ekonomi yang sering terjadi ditengarai adalah ulah sistem ekonomi konvensional, yang mengedepankan sistem bunga sebagai instrumen provitnya. Berbeda dengan apa yang ditawarkan sistem ekonomi syariah, dengan instrumen provitnya, yaitu sistem bagi hasil. Sistem ekonomi syariah sangat berbeda dengan ekonomi kapitalis, sosialis maupun komunis. Ekonomi syariah bukan pula berada di tengah-tengah ketiga sistem ekonomi itu. Sistem ekonomi syariah yang terbukti kebal terhadap krisis perlu disosialisasikan sejak dini, yaitu sejak siswa di sekolah khususnya sekolah berbasis Islam (Madrasah). Sosialisasi tersebut harus melibatkan semua guru termasuk guru matematika yang di dalamnya khusus membahas ekonomi konvensional yang rentan krisis [15].

Dalam kurikulum madrasah tsanawiyah, di samping matematika terdapat matapelajaran fiqh yang di dalamnya membahas tentang jual beli dan bagi hasil. Materi tersebut sangat berkaitan dengan materi matematika. Namun praktiknya guru belum melakukan integrasi antara matematika dengan figh (ekonomi syariah). Guru terkendala dengan terbatasnya bahan ajar yang memuat prinsip-prinsip ekonomi syariah.

Krisis ekonomi yang sering terjadi ditengarai adalah ulah sistem ekonomi konvensional, yang mengedepankan sistem bunga sebagai instrumen provitnya. Berbeda dengan apa yang ditawarkan sistem ekonomi syariah, dengan instrumen provitnya, yaitu sistem bagi hasil.

Sistem ekonomi syariah sangat berbeda dengan ekonomi kapitalis, sosialis maupun komunis. Ekonomi syariah bukan pula berada di tengah-tengah ketiga sistem ekonomi itu. Sangat bertolak belakang dengan kapitalis yang lebih bersifat individual, sosialis yang memberikan hampir semua tanggungjawab kepada warganya serta komunis yang ekstrem, ekonomi Islam menetapkan bentuk perdagangan serta perkhidmatan yang boleh dan tidak boleh di transaksikan. Ekonomi dalam Islam harus mampu memberikan kesejahteraan bagi seluruh masyarakat, memberikan rasa adil, kebersamaan dan kekeluargaan serta mampu memberikan kesempatan seluas-luasnya kepada setiap pelaku usaha.

Tidak banyak yang dikemukakan dalam Al Qur'an, dan hanya prinsip-prinsip yang mendasar saja. Karena alasan-alasan yang sangat tepat, Al Qur'an dan Sunnah banyak sekali membahas tentang bagaimana seharusnya kaum Muslim berprilaku sebagai produsen, konsumen dan pemilik modal, tetapi hanya sedikit tentang sistem ekonomi. Sebagaimana diungkapkan dalam pembahasan diatas, ekonomi dalam Islam harus mampu memberikan kesempatan seluas-luasnya kepada setiap pelaku usaha. Selain itu, ekonomi syariah menekankan empat sifat, antara lain: a) Kesatuan (unity), b) Keseimbangan (equilibrium), c) Kebebasan (free will), dan d) Tanggungjawab (responsibility)

Manusia sebagai wakil (khalifah) Tuhan di dunia tidak mungkin bersifat individualistik, karena semua (kekayaan) yang ada di bumi adalah milik Allah semata, dan manusia adalah kepercayaan-Nya di bumi. Di dalam menjalankan kegiatan ekonominya, Islam sangat mengharamkan kegiatan riba, yang dari segi bahasa berarti "kelebihan". Dalam Al Qur'an Surat Al Baqarah ayat 275 disebutkan bahwa Orang-orang yang makan (mengambil) riba tidak dapat berdiri melainkan seperti berdirinya orang yang kemasukan syaitan lantaran (tekanan) penyakit gila. Keadaan mereka yang demikian itu, adalah 
disebabkan mereka berkata (berpendapat), sesungguhnya jual beli itu sama dengan riba, padahal Allah telah menghalalkan jual beli dan mengharamkan riba...

Dalam penelitian ini, ekonomi syariah dibatasi pada perbankan syariah dan jual beli syariah. Pembatasan ini didasarkan pada kurikulum matematika MTs materi yang berhubungan dengan ekonomi syariah adalah aritmetika sosial yaitu bunga dan jual beli.

1. Perbankan Syariah

Suatu bentuk awal ekonomi pasar dan merkantilisme, yang oleh beberapa ekonom disebut sebagai "kapitalisme Islam", telah mulai berkembang antara abad ke-8 dan ke-12 [2] [16]. Perekonomian moneter pada periode tersebut berdasarkan mata uang dinar yang beredar luas saat itu, yang menyatukan wilayah-wilayah yang sebelumnya independen secara ekonomi.

Pada abad ke-20, kelahiran perbankan syariah tidak terlepas dari hadirnya dua gerakan renaisans Islam modern, yaitu gerakan-gerakan neorevivalis dan modernis [5] [14]. Sekitar tahun 1940-an, di Pakistan dan Malaysia telah terdapat upaya-upaya pengelolaan dana jamaah haji secara non konvensional. Tahun 1963, Islamic Rural Bank berdiri di desa Mit Ghamr di Kairo, Mesir [18].

Perbankan syariah memiliki tujuan yang sama seperti perbankan konvensional, yaitu agar lembaga perbankan dapat menghasilkan keuntungan dengan cara meminjamkan modal, menyimpan dana, membiayai kegiatan usaha, atau kegiatan lainnya yang sesuai. Prinsip hukum Islam melarang unsurunsur di bawah ini dalam transaksi-transaksi perbankan tersebut [19]:

a. Perniagaan atas barang-barang yang haram,

b. Bunga (

c. Perjudian dan spekulasi yang disengaja ( ميسرmaisir), serta

d. Ketidakjelasan dan manipulatif ( غرر gharar).

Perbandingan antara bank syariah dan bank konvensional adalah sebagai berikut [18]:

\section{Bank Islam:}

- Melakukan hanya investasi yang halal menurut hukum Islam

- Memakai prinsip bagi hasil, jual-beli, dan sewa

- Berorientasi keuntungan dan falah

- Hubungan dengan nasabah dalam bentuk kemitraan

- Penghimpunan dan penyaluran dana sesuai fatwa Dewan Pengawas Syariah

\section{Bank Konvensional:}

- Melakukan investasi baik yang halal atau haram menurut hukum Islam

- Memakai perangkat suku bunga

- Berorientasi keuntungan

- Hubungan dengan nasabah dalam bentuk kreditur-debitur

- Penghimpunan dan penyaluran dana tidak diatur oleh dewan sejenis

\section{Jual Beli dalam Islam}

Jual beli menurut bahasa artinya pertukaran atau saling menukar. Sedangkan menurut pengertian fikih, jual beli adalah menukar suatu barang dengan barang yang lain dengan rukun dan syarat tertentu. Jual beli juga dapat diartikan menukar uang dengan barang yang diinginkan sesuai dengan rukun dan syarat tertentu. Setelah jual beli dilakukan secara sah, barang yang dijual menjadi milik pembeli sedangkan uang yang dibayarkan pembeli sebagai pengganti harga barang, menjadi milik penjual [10].

Suatu ketika Rasulullah Muhammad SAW ditanya oleh seorang sahabat tentang pekerjaan yang paling baik. Beliau menjawab, pekerjaan terbaik adalah pekerjaan yang dilakukan dengan tangannya sendiri dan jual beli yang dilakukan dengan baik. Jual beli hendaknya dilakukan oleh pedagang yang mengerti ilmu fiqih. Hal ini untuk menghindari terjadinya penipuan dari ke dua belah pihak. Khalifah Umar bin Khattab, sangat memperhatikan jual beli yang terjadi di pasar. Beliau mengusir pedagang yang tidak memiliki pengetahuan ilmu fiqih karena takut jual beli yang dilakukan tidak sesuai dengan hukum Islam [13][14].

Jual beli sudah ada sejak dulu, meskipun bentuknya berbeda. Jual beli juga dibenarkan dan berlaku sejak zaman Rasulullah Muhammad SAW sampai sekarang. Jual beli mengalami perkembangan seiring pemikiran dan pemenuhan kebutuhan manusia. Jual beli yang ada di masyarakat di antaranya adalah: a) jual beli barter (tukar menukar barang dengan barang); b) money charger (pertukaran mata uang); c) jual beli kontan (langsung dibayar tunai); d) jual beli dengan 
cara mengangsur (kredit); e) jual beli dengan cara lelang (ditawarkan kepada masyarakat umum untuk mendapat harga tertinggi)[6].

Berbagai macam bentuk jual beli tersebut harus dilakukan sesuai hukum jual beli dalam agama Islam. Hukum asal jual beli adalah mubah (boleh). Allah SWT telah menghalalkan praktik jual beli sesuai ketentuan dan syariat-Nya. Dalam Surah al-Baqarah ayat 275 Allah SWT berfirman yang artinya Dan Allah telah menghalalkan jual beli dan mengharamkan riba(Q.S. al-Baqarah: 275).

Hukum jual beli ada 4 macam, yaitu: 1) Mubah (boleh), merupakan hukum asal jual beli; 2) Wajib, apabila menjual merupakan keharusan; 3) Sunah, misalnya menjual barang kepada sahabat atau orang yang sangat memerlukan barang yang dijual; dan 4) Haram, misalnya menjual barang yang dilarang untuk diperjualbelikan.

Jual beli dinyatakan sah apabila memenuhi rukun dan syarat jual beli. Rukun jual beli berarti sesuatu yang harus ada dalam jual beli. Menurut sebagian besar ulama, rukun jual beli ada empat macam, yaitu: a) Penjual dan pembeli, b) Benda yang dijual, c) Alat tukar yang sah (uang), d) Ijab Kabul.

Jual beli dikatakan sah, apabila memenuhi syarat-syarat yang ditentukan. Rasulullah Muhammad SAW melarang jual beli yang mengandung unsur tipuan. Adapun syarat sah jual beli adalah 1) penjual dan pembeli, 2) uang dan barang yang dijual, dan 3) ljab kabul.

Aritmetika sosial merupakan materi matematika MTs yang didalamnya membahas kegiatan ekonomi yang berkaitan dengan jual beli, untung-rugi, tabungan, pajak dan lain-lain. Di sisi lain, jual beli merupakan bagian yang tidak dapat dipisahkan dari kegiatan setiap orang. Selain itu, agar siswa lebih mengenal akad-akad bisnis dalam Islam maka perlu diperkenalkan tentang sistem bagi hasil. Lebih lanjut, ada banyak nilainilai dalam ekonomi syariah yang harus dimiliki siswa seperti jujur, amanah, ikhlas, dermawan, tawadhu, menjalin relasi, hubungan dengan keluarga, hubungan dengan orangtua, menjauhi usaha yang syubhat dan haram, amar maruf nahi munkar, kerja keras dan lain-lain. Nilainilai tersebut juga bisa diterapkan pada materi aritmetika sosial.

1. Harga pembelian, harga penjualan, untung, dan rugi

Dalam kegiatan perdagangan terdapat penjual barang dan pembelinya. Penjual menyerahkan barang kepada pembeli, sedangkan pembeli menyerahkan uang sebagai pengganti barang-barang yang diterimanya. Untuk memperoleh barang-barang yang akan dijual, penjual membeli dari pabrik, grosir atau tempat lainnya. Harga barang dari pabrik, grosir, atau tempat lainnya disebut harga pembelian atau modal. Sementara itu uang yang diterima oleh pedagang dari hasil penjualan barang disebut harga penjualan. Dengan demikian, kegiatan perdagangan selalu berkaitan dengan harga pembelian atau modal yang menjadi dasar perhitungan. Dalam perdagangan, terdapat dua kemungkinan yang akan dialami oleh pedagang, yaitu pedagang itu akan mendapat untung atau pedagang itu akan mendapat rugi [1]. Penjual dikatakan untung jika harga penjualan lebih tinggi daripada harga pembelian sebagaimana rumus berikut [4].

$$
\text { Untung = Harga Penjualan - Harga Pembelian }
$$

Penjual dikatakan mengalami rugi jika harga penjualan lebih rendah daripada harga pembelian (modal) sebagaimana rumus berikut.

$$
\text { Rugi = Harga Pembelian - Harga Penjualan }
$$

2. Bunga dan Bagi Hasil

Apabila menyimpan uang di bank, maka akan mendapatkan tambahan uang yang disebut bunga. Bunga tabungan dihitung berdasarkan perseb nilai. Bunga tabungan dihitung secaraperiodik, misalnya sebulan sekali atau setahun sekali. Ada dua jenis bunga tabungan, yaitu bunga tunggal dan bunga majemuk. Bunga tunggal adalah bunga yang dihitung hanya berdasarkan besarnya modal saja, sedangkan bunga majemuk adalah bunga yang dihitung berdasarkan besarnya modal dan bunga [12].

Bagi hasil adalah suatu sistem yang meliputi tata cara pembagian hasil usaha antara penyedia dana dengan pengelola dana. Pembagian hasil usaha ini dapat terjadi antara bank dengan penyimpan dana, maupun antara bank dengan nasabah penerima dana. Bentuk produk yang 
berdasarkan prinsip ini adalah mudharabah dan musyarakah. Lebih lanjut prinsip mudharabah dapat digunakan sebagai dasar untuk produk pendanaan (tabungan dan deposito) maupun pembiayaan, sedangkan musyarakah lebih banyak untuk pembiayaan [11].

Pembelajaran matematika di MTs wilayah Yogyakarta sudah menggunakan buku teks. Namun demikan, buku teks yang digunakan masih bersifat umum dan belum berbasis ekonomi syariah. Padahal, sangat penting mengintegrasikan nilai-nilai ekonomi syariah dalam pembelajaran matematika khususnya pada materi aritmetika sosial. Bahan ajar dengan materi aritmetika sosial akan diintegrasikan dengan nilai-nilai keislaman, yaitu jujur, amanah, ikhlas, tawadhu, dermawan, menjalin relasi, hubungan dengan keluarga, hubungan dengan orang tua, menjauhi usaha yang syubhat dan haram, dan amar maruf nahi munkar.

Tujuan penelitian pengembangan ini adalah menghasilkan bahan ajar matematika berbasis ekonomi syariah untuk siswa madrasah tsanawiyah dan mengetahui kelayakannya.

\section{Metodologi Penelitian}

Penelitian ini merupakan penelitian pengembangan (Research and Development). Penelitian pengembangan ini menggunakan model pengembangan prosedural yaitu model yang bersifat deskriptif yang menggariskan langkah-langkah yang harus diikuti untuk menghasilkan produk. Tahap-tahap pengembangan prosedural antara lain tahap perencanaan, pelaksanaan, dan penilaian produk.

Model pengembangan media pembelajaran yang digunakan dalam penelitian ini menggunakan langkah-langkah yang diadaptasi dari Borg \& Gall [17], yaitu sebagai berikut:

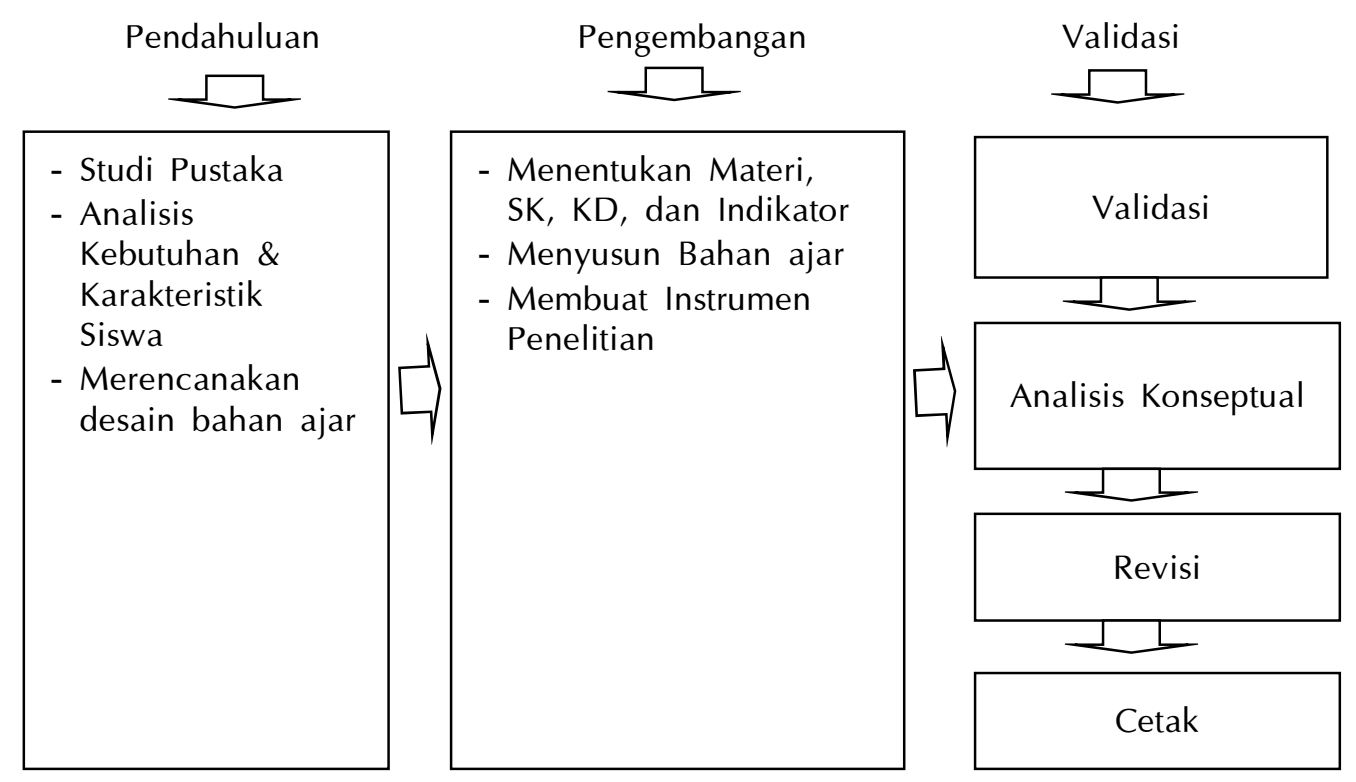

Gambar 1 Model Pengembangan Media Pembelajaran.

Prosedur pengembangan merupakan penjelasan dari model pengembangan yang telah ditetapkan. Langkah-langkah yang ditempuh dalam prosedur pengembangan yaitu:

1. Pendahuluan

a. Studi pustaka, yaitu mengkaji teori-teori dan hasil penelitian yang relevan dengan penelitian dan pengembangan yang akan dilakukan.

b. Menganalisis kebutuhan dan karakteristik siswa. Analisis kebutuhan ini dilakukan melalui pengamatan terhadap karakteristik siswa dalam pembelajaran matematika.

c. Merencanakan dan memilih desain bahan ajar. 
2. Pengembangan

a. Menentukan standar kompetensi, kompetensi dasar, indikator, dan materi pokok yang akan disajikan.

b. Menyusun bahan ajar matematika berbasis ekonomi syariah yang fokus membahas materi aritmetika sosial kelas VII semester I.

c. Pembuatan instrumen penelitian dengan validasi ahli sebagai alat ukur kualitas bahan ajar, respon siswa terhadap bahan ajar, dan pemahaman konsep siswa.

3. Validasi
a. Validasi oleh Ahli
Validasi oleh ahli atau uji pengembangan terbatas ini merupakan kegiatan melakukan uji awal terhadap desain produk kepada ahli yang berkompeten. Validasi bahan ajar yang dibuat kepada validator dengan instrumen yang sesuai untuk mendapatkan penilaian, saran, dan masukan.
b. Analisis Konseptual
Analisis konseptual merupakan kegiatan menganalisis konsep-konsep materi pembelajaran yang ada di dalam bahan ajar berdasarkan atas saran/masukan yang telah diberikan oleh ahli.
c. Revisi I
Revisi I merupakan tindak lanjut atas analisis konseptual yang telah dilakukan. Revisi ini untuk menyempurnakan berbagai kekurangan yang terdapat pada bahan ajar berdasarkan atas saran/masukan dari ahli.

\section{Data dan Sumber Data}

Data dalam penelitian ini meliputi:

1. Karakteristik siswa

Data ini berisi tentang karakteristik siswa yang akan digunakan sebagai bahan pengembangan bahan ajar. Sumber data adalah siswa

2. Kebutuhan guru

Data ini tentang kebutuhan guru terhadap bahan ajar berbasis syariah. Sumber data adalah guru

3. Kualitas bahan ajar

Data kualitas bahan ajar digunakan untuk mengetahui kualitas bahan ajar dari segi pemuatan ekonomi syariah secara tersirat, tersurat, dan keseluruhan. Data ini diambil dari validator ahli.

\section{Teknik Analisis Data}

Data yang diperoleh dalam penelitian ini akan dianalisis melalui tahapan sebagai berikut:

1. Data kualitatif yang diperoleh dari angket secara kualitatif.

2. Data yang diperoleh lembar validasi yang berupa huruf diubah menjadi nilai kualitatif dengan langkah-langkah sebagai berikut:

a. Jenis data yang diambil berupa data kualitatif dengan menggunakan skala Likert kemudian diubah menjadi kuantitatif dengan ketentuan yang dapat dilihat dalam Tabel 1 sebagai berikut:

Tabel 1 Aturan pemberian Skala.

\begin{tabular}{lc}
\hline Keterangan & Skor \\
\hline SB (sangat baik) & 5 \\
B (baik) & 4 \\
C (cukup) & 3 \\
K (kurang) & 2 \\
SK (sangat kurang) & 1 \\
\hline
\end{tabular}

b. Setelah data terkumpul, kemudian menghitung skor rata-rata

c. Mengubah nilai tiap aspek kriteria dalam masing-masing komponen bahan ajar matematika menjadi nilai kualitatif sesuai dengan kriteria kategori penilaian ideal dengan ketentuan dalam Tabel 2 berikut (Sudijono, 1987: 161): 
Tabel 2 Kriteria Kategori Penilaian Ideal.

\begin{tabular}{lll}
\hline No & $\begin{array}{l}\text { Rentang skor } \\
\text { kuantitatif }(x)\end{array}$ & $\begin{array}{l}\text { Kategori } \\
\text { Kualitatif }\end{array}$ \\
\hline 1 & $x>80 \%$ & Sangat Baik \\
2 & $70 \%<x \leq 80 \%$ & Baik \\
3 & $60 \%<x \leq 70 \%$ & Cukup \\
4 & $50 \%<x \leq 60 \%$ & Kurang \\
5 & $x \leq 50 \%$ & Sangat Kurang \\
\hline
\end{tabular}

Menentukan nilai keseluruhan bahan matematika dengan menghitung skor kemudian diubah menjadi nilai kualitatif sesuai dengan kriteria kategori penilaian ideal pada Materi Pokok Aritmetika Sosial

\section{Hasil dan Pembahasan}

\section{Hasil Penelitian}

Hasil penelitian pengembangan ini adalah tersusunnya bahan ajar matematika berbasis ekonomi syariah untuk siswa madrasah tsanawiyah pada materi pokok aritmetika sosial. Bahan ajar tersebut dikemas dalam bentuk buku.

Produk bahan ajar matematika ini memuat materi yang tercakup dalam Standar kompetensi Menggunakan bentuk aljabar, persamaan dan pertidaksamaan linear satu variabel, dan perbandingan dalam pemecahan masalah dan dalam kompetensi dasar Menggunakan konsep aljabar dalam menyelesaikan masalah aritmatika sosial sederhana dengan materi aritmetika sosial yang meliputi materi nilai keseluruhan dan nilai perunit, harga beli, harga jual, dan untung, dan aplikasi bentuk persen dalam kehidupan (tabungan, koperasi, dan pajak).

Proses pengembangan bahan ajar materi aritmetika sosial berdasarkan pembelajaran kontekstual dan nilai-nilai Islam ini dilakukan dengan menggunakan model pengembangan Borg \& Gall dengan tahaptahap pendahuluan, pengembangan, dan validasi. Adapun hasil penelitian pengembangan pada setiap tahapan secara lebih rinci dipaparkan sebagai berikut.

1. Tahap Pendahuluan

a. Studi Pustaka

Studi pustaka dilakukan dengan mengumpulkan dan memilih pustaka tentang aritmetika sosial dan ekonomi syariah serta sistem bank syariah. Hal ini dilakukan agar bahan ajar mampu memberi gambaran jelas tentang ekonomi syariah dikaitkan dengan aritmetika sosial,

b. Analisis Kebutuhan dan Karakteristik

Analisis kebutuhan guru diberikan dalam bentuk angket kepada tiga guru matematika. Hasil analisis kebutuhan guru adalah sebagai berikut:

- Matematika merupakan pelajaran yang menarik, menantang, pemasalahan yang rumit dan dapat diselesaikan adalah kepuasan tersendiri, namun sulit dalam mengajarkan.

- Materi aritmetika sosial adalah materi yang mudah namun sulit diajarkan karena harus melibatkan model matematika.

- Bahan ajar yang digunakan masih terbatas pada buku teks dan LKS yang diperoleh dengan mendowload.

- Belum ada bahan ajar matematika yang secara khusus mengkaitkan materi matematika dengan ekonomi syariah.

- Pengkaitan nilai islam dalam dengan menghubungkan ayat yang berkaitan dengan materi dan engaitkannya dengan materi, tetapi terkadang sulit mengaitkan materi matematika dengan islam.

- Guru membutuhkan bahan ajar matematika yang dikaitkan dengan ekonomi syariah karena sekolah islam sehingga perlu adanya implementasi materi ajar ke kehidupan yang berlandaskan 
nilai islam, sekolah menuntut untuk mengajarkannya, dan untuk menyeimbangkan pengalaman beragama dan pengetahuan.

c. Analisis Karakteristik Siswa

Analisis karakteristik siswa dilakukan melalui pemberian angket kepada 45 siswa. Hasil angket siswa adalah:

- Matematika merupakan pelajaran yang menarik tapi sulit.

- Materi aritmetika sosial adalah materi yang paling sulit dipahami siswa karena melibatkan model matematika dan perhitungan bulan dan tahun namun paling menarik untuk dipelajari.

- Siswa lebih suka belajar sendiri yang diselingi dengan belajar kelompok.

- Siswa memerlukan bahan ajar agar mudah memahami matematika dan nilai-nilai islam (ekonomi syariah).

- Guru belum banyak menanamkan nilai-nilai Islam dalam pembelajaran matematika dan hanya mengawali dengan tadarrus saja.

Kondisi tersebut menggambarkan bahwa guru dan siswa membutuhkan bahan ajar matematika yang melibatkan nilai-nilai islam (ekonomi syariah) dalam rangka menyatukan matematika dengan pemahaman agama Islam. Di samping itu, guru menyadari bahwa menanamkan nilai-nilai Islam dalam pembelajaran matematika sangat mungkin dilakukan. Untuk itu, peneliti akan bahan ajar yang tidak hanya memberi pemahaman konsep aritmetika sosial, namun sekaligus mempromosikan ekonomi syariah sejak dini pada siswa.

d. Merencanakan Desain Bahan Ajar

Desain bahan ajar yang digunakan adalah:

- Berbentuk buku teks

- Diawali dengan serangkaian masalah untuk membandingkan konvensional dan syariah

- Berisi tentang pedoman dalam ekonomi syariah

- Berisi materi aritmetika sosial

- Berisi latihan soal untuk mengukur pemahaman konsep dan pemecahan masalah

2. Tahap Pengembangan

a. Menentukan SK, KD, Indikator, dan Materi

Tabel 3 SK, KD, dan Indikator.

\begin{tabular}{|c|c|}
\hline i Ir & Menghargai dan menghayati ajaran agama yang dianutnya \\
\hline Kompetensi Inti 2 & $\begin{array}{l}\text { Menghargai dan menghayati perilaku jujur, disiplin, tanggungjawab, peduli (toleransi, } \\
\text { gotong royong), santun, percaya diri, dalam berinteraksi secara efektif dengan } \\
\text { lingkungan sosial dan alam dalam jangkauan pergaulan dan keberadaannya. }\end{array}$ \\
\hline Kompetensi Inti 3 & $\begin{array}{l}\text { Memahami pengetahuan (faktual, konseptual, dan prosedural) berdasarkan rasa ingin } \\
\text { tahunya tentang ilmu pengetahuan, teknologi, seni, budaya terkait fenomena dan } \\
\text { kejadian tampak mata }\end{array}$ \\
\hline ensi Inti 4 & $\begin{array}{l}\text { Mencoba, mengolah, dan menyaji dalam ranah konkret (menggunakan, mengurai, } \\
\text { merangkai, memodifikasi, dan membuat) dan ranah abstrak (menulis, membaca, } \\
\text { menghitung, menggambar, dan mengarang) sesuai dengan yang dipelajari di sekolah } \\
\text { dan sumber lain yang sama dalam sudut pandang/teori }\end{array}$ \\
\hline $\begin{array}{l}\text { Stan } \\
\text { Kom }\end{array}$ & $\begin{array}{l}\text { Menggunakan bentuk aljabar, persamaan dan pertidaksamaan linear satu variabel, } \\
\text { dan perbandingan dalam pemecahan masalah }\end{array}$ \\
\hline Kompetensi Dasar & $\begin{array}{l}\text { Menggunakan konsep aljabar dalam menyelesaikan masalah aritmatika sosial } \\
\text { sederhana }\end{array}$ \\
\hline Indik & $\begin{array}{l}\text { - Menentukan nilai perunit dalam proses jual beli } \\
\text { - Menentukan nilai keseluruan dalam proses jual beli } \\
\text { - Menentukan harga jual dalam proses jual beli } \\
\text { - Menentukan harga beli dalam proses jual beli } \\
\text { - Menentukan keuntungan dalam proses jual beli } \\
\text { - Menentukan sah tidaknya jual beli menurut Islam dengan menggunakan konsep } \\
\text { keuntungan } \\
\text { - Menentukan bunga dalam tabungan } \\
\text { - Memilih sistem syariah atau konvensional dalam menabung }\end{array}$ \\
\hline
\end{tabular}


Materi aritmetika sosial merupakan materi yang banyak bersentuhan dengan kehidupan seharihari. Dalam setiap penyajian materi, peneliti memasukkan masalah kontekstual dan dikaitkan dengan nilai-nilai Islam, di antaranya jual beli yang sah dan tidak sah, membandingkan tabungan dan kredit antara sistem syariah dan konvensional, dan menjelaskan mengapa riba itu diharamkan. Setelah masalah, peneliti menyajikan materi yang didesain agar siswa mampu menemukan konsep dan rumus yang dikehendaki beserta contoh-contoh menggunakan rumus yang diperoleh, dan setiap akhir materi disajikan uji kompetensi yang berisi soal-soal yang menantang dan disajikan interaktif sehingga siswa mengetahui apakah jawabannya salah atau benar sekaligus mengetahui pembahasannya.

b. Menyusun Bahan ajar

Bahan ajar awal ini berupa bahan ajar jadi sementara dari hasil desain. Sebelum melalui tahap selanjutnya bahan ajar ini didiskusikan bersama dosen di Program Studi Pendidikan Matematika. Hasil diskusi kemudian ditindaklanjuti dengan revisi I. Setelah merevisi model bahan ajar yang akan dikembangkan peneliti menyusun materi aritmetika sosial, menentukan masalah-masalah yang berhubungan dengan aritmetika sosial dan ekonomi syariah, dan menentukan ekonomi syariah yang akan dimunculkan dalam modul.

Bahan ajar yang dikembangkan menggunakan pendekatan kontekstual. Penyajian han baberawal dari permasalahan kontekstual. Dari permasalahan tersebut dikonstruk menjadi pertanyaan-pertanyaan sehingga siswa dengan sendirinya mampu menyimpulkan materi yang sedang dipelajari. Bahan ajar matematika ini lebih menggunakan pendekatan konstruktivisme pada penyajiannya.

c. Membuat Instrumen Penelitian

Instrumen yang dibuat adalah lembar penilaian bahan ajar.

\section{Tahap Validasi}

Pada tahapan ini peneliti melakukan koreksi dan penilaian bahan ajar yang dikembangkan. Penilaian meliputi aspek tampilan dan aspek materi. Aspek tampilan berisi tentang tata warna, tata letak, dan penyajian. Sedangkan aspek materi meliputi kesesuaian dengan kompetensi dasar dan indikator, tata bahasa, urutan materi, unsur-unsur nilai Islam, masalah kontekstual, dan materi yang menantang keaktifan siswa dan motivasi siswa untuk belajar. Penilaian dilakukan oleh tiga orang guru matematika. Berikut adalah hasil penilaian

a. Hasil penilaian bahan ajar pembelajaran aspek materi.

Tabel 4 Hasil Penilaian Bahan Ajar Aspek Materi.

\begin{tabular}{|c|c|c|c|c|}
\hline \multirow{2}{*}{ No } & \multirow{2}{*}{ Indikator } & \multicolumn{3}{|c|}{ Validator } \\
\hline & & 1 & 2 & 3 \\
\hline 1 & $\begin{array}{l}\text { Isi materi memuat konsep yang benar sesuai dengan Standar Kompetensi (SK) } \\
\text { dan Kompetensi Dasar (KD) }\end{array}$ & 5 & 5 & 5 \\
\hline 2 & Materi dijabarkan jelas & 5 & 4 & 5 \\
\hline 3 & Materi yang tertata dalam tampilan rinci & 5 & 3 & 4 \\
\hline 4 & Di dalam bahan ajar matematika terdapat pengembangan konsep matematika & 4 & 4 & 5 \\
\hline 5 & $\begin{array}{l}\text { Soal yang dibuat sesuai dengan isi materi yang ada dalam bahan ajar } \\
\text { matematika }\end{array}$ & 5 & 4 & 4 \\
\hline 6 & Menggunakan ejaan bahasa yang sesuai dengan EYD Bahasa Indonesia & 4 & 4 & 5 \\
\hline 7 & Menggunakan bahasa yang komunikatif & 4 & 4 & 5 \\
\hline 8 & Menggunakan bahasa yang mudah dipahami & 4 & 4 & 5 \\
\hline 9 & Menggunakan bahasa baku & 4 & 4 & 5 \\
\hline 10 & $\begin{array}{l}\text { Menggunakan bahasa yang sesuai dengan perkembangan intelektual peserta } \\
\text { didik }\end{array}$ & 4 & 4 & 4 \\
\hline 11 & Bahan ajar matematika dapat memotivasi peserta didik & 5 & 3 & 5 \\
\hline 12 & Bahan ajar matematika memuat unsur-unsur hiburan & 4 & 4 & 4 \\
\hline 13 & Bahan ajar matematika membantu keaktifan (keterlibatan) peserta didik & 4 & 4 & 4 \\
\hline 14 & Bahan ajar matematika mendorong kesenangan dalam belajar & 5 & 5 & 4 \\
\hline 15 & Bahan ajar matematika memuat masalah-masalah kontekstual & 4 & 4 & 5 \\
\hline 16 & $\begin{array}{l}\text { Bahan ajar matematika memuat masalah yang bermanfaat untuk kehidupan } \\
\text { siswa kelak }\end{array}$ & 4 & 3 & 5 \\
\hline
\end{tabular}




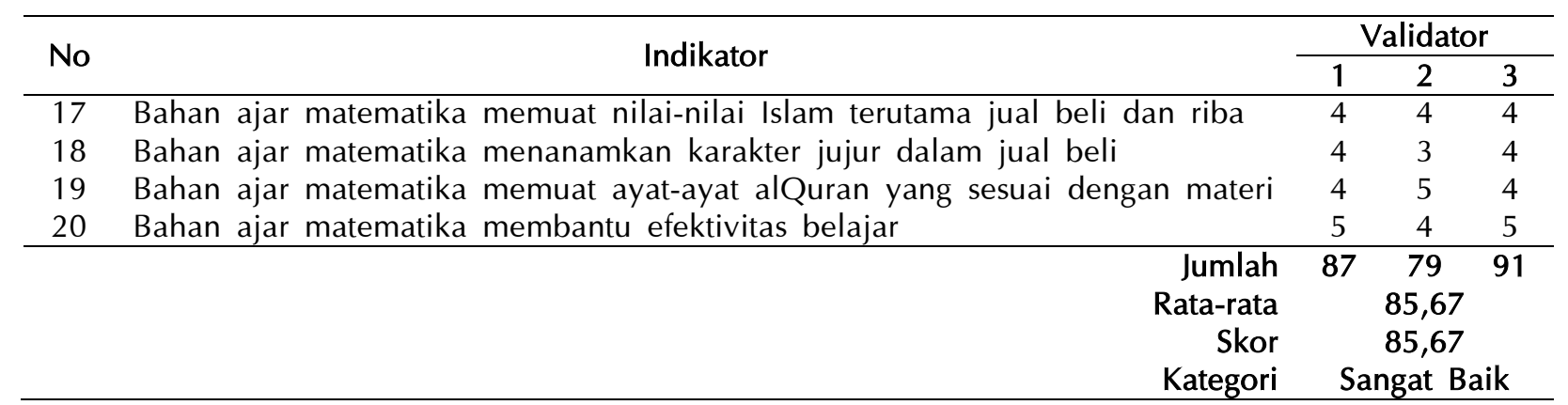

Berdasarkan penilaian dari tiga orang guru pada aspek materi memperoleh skor rata-rata 85,67 atau dengan kategori Sangat Baik.

b. Hasil penilaian bahan ajar pembelajaran aspek tampilan.

Tabel 5 Hasil Penilaian Bahan Ajar Pembelajaran Aspek Tampilan.

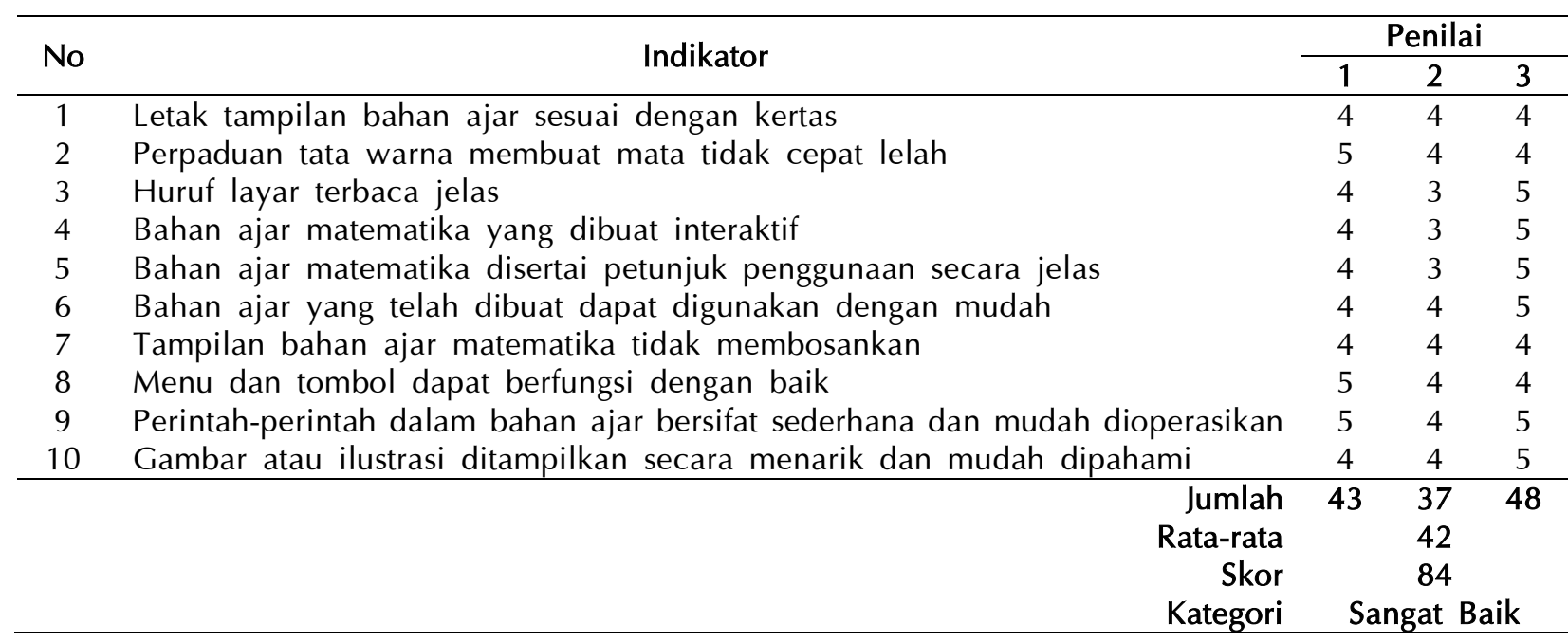

Berdasarkan penilaian dari tiga orang guru pada aspek tampilan memperoleh skor rata-rata 84 atau dengan kategori Sangat Baik.

Berdasarkan kriteria keberhasilan, maka bahan ajar matematika materi aritmetika sosial berbasis ekonomi syariah layak digunakan sebagai sumber belajar.

\section{Pembahasan}

Berdasarkan diskripsi hasil penelitian yang diuraikan sebelumnya, pengembangan bahan ajar matematika berbasis ekonomi syariah dilakukan berdasarkan model pengembangan Borg \& Gall yang meliputi tahap pendahuluan, tahap pengembangan, dan tahap validasi. Karena keterbatasan waktu, tahap validasi hanya dilakukan sampai penilaian ahli.

Pada tahap pendahuluan dilakukan studi pustaka, analisis kebutuhan dan karakteristik, dan merencanakan desain bahan ajar. Studi pustaka dilakukan dengan mengumpulkan dan memilih pustaka tentang aritmetika sosial dan ekonomi syariah serta sistem bank syariah. Hal ini dilakukan agar bahan ajar mampu memberi gambaran jelas tentang ekonomi syariah dikaitkan dengan aritmetika sosial . Analisis kebutuhan guru diberikan dalam bentuk angket kepada tiga guru matematika. Hasil analisis kebutuhan guru adalah sebagai berikut belum ada bahan ajar matematika yang secara khusus mengkaitkan materi matematika dengan ekonomi syariah dan guru membutuhkan bahan ajar matematika yang dikaitkan dengan ekonomi syariah karena sekolah islam sehingga perlu adanya implementasi materi ajar ke kehidupan yang berlandaskan nilai islam, sekolah menuntut untuk mengajarkannya, dan untuk menyeimbangkan pengalaman beragama dan pengetahuan. Dari analisis karakteristik siswa diperoleh fakta bahwa matematika merupakan pelajaran yang menarik tapi sulit, materi aritmetika sosial adalah materi yang paling sulit dipahami siswa karena melibatkan model 
matematika dan perhitungan bulan dan tahun namun paling menarik untuk dipelajari, dan siswa lebih suka belajar sendiri yang diselingi dengan belajar kelompok. Pada tahap perencanaan desain dihasilkan bahan ajar berbentuk buku teks, diawali dengan serangkaian masalah untuk membandingkan konvensional dan syariah yang bisa dikerjakan secara mandiri atau diskusi, berisi tentang pedoman dalam ekonomi syariah, berisi materi aritmetika sosial, dan berisi latihan soal untuk mengukur pemahaman konsep dan pemecahan masalah.

Pada tahap pengembangan dilakukan dengan menganalisis SK dan KD untuk selanjutnya dibuat indikator pembelajaran dan materi yang dimasukkan. Tahap ini juga peneliti menyusun bahan ajar dan instrumen penelitian.

Berdasarkan analisa peneliti, kelebihan dan kekurangan bahan ajar matematikayang telah dikembangkan, antara lain sebagai berikut:

1. Kelebihan produk bahan ajar matematika berbasis ekonomi syariah yang telah dikembangkan adalah: tampilan menarik, disertai ilustrasi-ilustrasi masalah tentang materi-materi Aritmetika Sosial dan ekonomi syariah, serta ilustrasi tentang jual beli dan menabung yang sesuai dengan syariah.

2. Kekurangan produk bahan ajar matematika berbasis ekonomi syariah yang telah dikembangkan adalah: soal-soal latihan dan soal-soal uji kompetensi belum diacak secara random.

Karena penilaian media pembelajaran berbasis pendekatan kontekstual dan nilai-nilai Islam dikategorikan sangat baik untuk aspek materi, baik untuk aspek media dan sangat baik untuk aspek kualitas teknis maka bahan ajar matematika berbasis ekonomi syariah tersebut layak digunakan dalam pembelajaran matematika [3].

\section{Kesimpulan dan Saran}

\section{Kesimpulan}

Bahan ajar matematika dikembangkan dengan yang memuat masalah, pendahuluan, uraian materi, dan uji kompetensi. Setiap materi diawali dengan masalah yang kontekstual dan memasukkan sistem ekonomi syariah yang akan dipelajari siswa. Bahan ajar matematika dikemas dalam bentuk buku ajar tersebut dikembangkan dengan tahap pendahuluan, pengembangan, dan validasi.

Setelah dilakukan pengembangan, bahan ajar matematika tersebut nilai kelayakannya dengan kategori Sangat Baik untuk aspek tampilan dan Sangat Baik untuk aspek materi. Dengan kriteria sangat baik tersebut, bahan ajar matematika layak untuk digunakan dalam pembelajaran matematika pada materi aritmetika sosial.

\section{Saran}

Penelitian ini termasuk penelitian pengembangan bahan ajar yang berbentuk buku teks yang dikembangkan dengan besis ekonomi syariah. Adapun saran pemanfaatan dan pengembangan produk tindak lanjut adalah:

1. Diujicobakan di beberapa sekolah untuk mendapatkan hasil yang lebih beragam sehingga penggunaan bahan ajar berbasis berbasis ekonomi syariah ini nantinya mencapai tujuan yang diharapkan yaitu dapat memfasilitasi pemahaman siswa dengan baik.

2. Digunakan pada proses pembelajaran matematika.

3. Bahan ajar matematika berbasis ekonomi syariah pada materi pokok Aritmetika Sosial untuk siswa SMP kelas VII semester ganjil ini dapat digunakan, dikembangkan dan diperbaiki lebih lanjut untuk digunakan pada kegiatan penelitian-penelitian selanjutnya, selain itu dapat juga digunakan sebagai sumber belajar selain buku cetak di sekolah agar guru lebih kreatif dan siswa lebih aktif dalam pembelajaran.

\section{Ucapan Terimakasih}

Penulis mengucapkan terima kasih kepada pimpinan UIN Sunan Kalijaga yang memberi dana penelitian melalui LPPM UIN Sunan Kalijaga. Ucapan terima kasih juga penulis haturkan kepada pimpinan Fakultas Sains dan Teknologi dan Prodi Pendidikan Matemtika UIN Sunan Kalijaga Yogyakarta yang memberi fasilitas kepada penulis. 


\section{Referensi}

[1] Adinawan, M. Cholik \& Sugiyono. 2010. Mathematics for Junior High School Grade VII $1^{\text {st }}$ Semester. Jakarta: Erlangga.

[2] Afzalur Rahman. 1980. Islamic Doctrine on Banking and Insurance. London: Muslim Trust Company.

[3] Arsyad, Azhar. 1997. Media Pembelajaran. Jakarta: Raja Grafindo Persada

[4] Cunayah, Cucun. 2011. Ringkasan dan Bank Soal Matematika untuk SMP. Bandung: Yrama Widia.

[5] http://www.imf.org/external/pubs/ft/wp/2008/wp0816.pdf Is/amic Banks and Financial Stability: An Empirical Analysis, hlm. 5

[6] https://archive.is/20121206032354/www.iran-daily.com/1388/12/11/MainPaper/3630/ Page/5/Index.htm

[7] Huda, Miftahul. 2013. Model-Model Pengajaran dan Pembelajaran: Isu-Isu Metodis dan Paradigmatis. Yogyakarta: Pustaka Pelajar

[8] Ismunanto, A. 2011. Ensklopedia Matematika. Jakarta : Lentera Abadi

[9] Kemendikbud. 2013. Kurikulum 2013. Jakarta: Kemendikbud

[10] Khursid Ahmad. 1999. Islamic Finance and Banking: The Challenge of the $21^{\text {st }}$ Century, dalam Imtiyazuddin Ahmad (ed.) Islamic Banking and Finance: The Concept, The Practice and The Challenge. Plainfield: The Islamic Society of North America.

[11] Muhammad \& Suwiknyo, Dwi. 2009. Akuntansi Perbankan Syariah. Jakarta: Trustmedia.

[12] Nurhaini, Dewi dan Wahyuni Tri. 2008. Matematika Konsep dan Aplikasinya. Jakarta: CV Usaha Makmur.

[13] Rammal, H. G., Zurbruegg, R. 2007. Awareness of Islamic Banking Products Among Muslims: The Case of Australia. dalam Journal of Financial Services Marketing, 12(1), 65-74.

[14] Saeed, Abdullah. 1996. Islamic Banking and Interest: A Study of the Prohibition of Riba and its Contemporary Interpretation. Leiden, Netherlands: E.J.Brill.

[15] Slater, Joanna. 2007. "World's Assets Hit Record Value Of \$140 Trillion". The Wall Street Journal.

[16] Subhi Y. Labib. 1969. Capitalism in Medieval Islam dalam The Journal of Economic History, 29 (1), hlm. 79-96 [81, 83, 85, 90, 93, 96].

[17] Sugiyono. 2010. Metode Penelitian Kuantitatif, Kualitatif, dan R\&D. Bandung: Alfabeta.

[18] Syafi'i Antonio, Muhammad. 2001. Bank Syariah, Dari Teori ke Praktik, penyunting Dadi M.H. Basri, Farida R. Dewi, Cet. 1, Jakarta: Gema Insani Press. ISBN 979-561-688-9.

[19] UU RI No. 21 Tahun 2008 tentang Perbankan Syariah. 